\title{
LICHEN-BAGS AS A BIOMONITORING TECHNIQUE IN AN URBAN AREA
}

\author{
Petrova, S.P. ${ }^{1 *}-$ YuruKova, L.D. ${ }^{2}-$ VelChEVA, I.G. ${ }^{1}$ \\ ${ }^{1}$ University of Plovdiv "Paisii Hilendarski”, Faculty of Biology, Department of Ecology and \\ Environmental Conservation, Plovdiv 4000, Tzar Assen Str. 24, Bulgaria \\ (phone: +359-32-261519) \\ ${ }^{2}$ Bulgarian Academy of Sciences, Institute of Biodiversity and Ecosystem Research, Sofia 1113, \\ Acad. G. Bonchev Str., Bl. 23, Bulgaria \\ *Corresponding author: \\ e-mail: slaveya_petrova@uni-plovdiv.bg \\ (Received $16^{\text {th }}$ Oct 2014; accepted $10^{\text {th }}$ Feb 2015)
}

\begin{abstract}
The suggested work presents the first application of the lichen-bags technique in the city of Plovdiv (Bulgaria). Plovdiv was pointed as one of the most polluted cities in Europe for 2008 by National Institute of Statistics of Italy (ISTAT, 2011). The study was carried out to estimate the air quality in the areas with high traffic activity, industrial and suburban zones by means of lichens. For this purpose, the concentrations of 21 chemical elements (Al, As, Ca, Cd, Cr, Co, Cu, Fe, Hg, K, Mg, Mn, Na, Ni, P, Pb, S, $\mathrm{Sr}, \mathrm{U}, \mathrm{V}$ and $\mathrm{Zn}$ ) were investigated using Pseudevernia furfuracea (L.) Zopf. samples in bags, which were exposed at 4 different sites in the city of Plovdiv. The elements $\mathrm{Na}, \mathrm{Mn}, \mathrm{Cu}, \mathrm{Zn}$ and $\mathrm{Sr}$ increased significantly their concentrations in the lichen-bags, whereas $\mathrm{K}, \mathrm{S}$ and $\mathrm{Cd}$ decreased theirs in comparison with the unexposed lichenized fungi. Highest values of RAF (relative accumulation factor) were found for $\mathrm{Na}$ (3.49), $\mathrm{Zn}$ (2.92) and $\mathrm{Cu}$ (3.33).
\end{abstract}

Keywords: atmospheric pollution, urbanization, active biomonitoring, lichen-bags, Pseudevernia furfuracea

\section{Introduction}

Since the beginning of the twentieth century, air pollution has worsened as a consequence of urbanization and industrialization, together with the rapid growth of the motorized transportation and population. Of the main components of air pollution, an important group to be considered is that of heavy metals, mostly associated with airborne particulate matter. This is particularly true in city centers, where vehicle engines, as well as the heating systems inside buildings, represent the most important sources of air pollution (Sawidis et al., 1995; Monaci et al., 2000).

Lichens are widely used in biomonitoring studies of air pollution, either as bioindicators of air quality or as bioaccumulators of atmospheric deposition (Conti and Geccheti, 2001; Sczepaniak and Bizuik, 2003; Cansaran-Duman et al., 2012). These organisms can be easily sampled, are low in cost, and allow wide areas to be monitored. Moreover, lichens do not have root systems or waxy cuticles, and thus they are strongly dependent on wet and dry deposition for their mineral nutrients (Bermudez et al., 2009). Unlike many other plants, they lack variability in morphology throughout the growing season, thus they are used for biomonitoring purposes in many ways (Giordano et al., 2005).

Some lichen species were successfully applied from many years for assessing the atmospheric deposition of heavy metals and toxic elements in background and polluted areas. Lichens naturally occur in many terrestrial ecosystems, but the anthropogenic 
factors can be responsible for their lack in urban areas. In such cases, the passive biomonitoring is not useful and the active biomonitoring comes to replace it. One of the techniques is exposing bags containing lichen in the polluted area to measure concentrations of contaminants affecting the samples (Adamo et al., 2003; Giordano et al., 2005; Yildiz et al., 2008).

This technique has a lot of advantages: well-defined exposure time, known original concentration of elements in the biomonitor, flexibility both in site selection and in number of stations that can be chosen. The major limitations of the method are in the unknown collection efficiency for different contaminants in different biomonitors and, therefore, the impossibility to standardize the exposure time for the exact species in bags and/or for urban, industrial or other source of pollution.

The suggested work shows the first application of the lichen-bags technique in the city of Plovdiv (Bulgaria). Furthermore, Plovdiv was pointed as one of the most polluted cities in Europe for 2008 by National Institute of Statistics of Italy (ISTAT, 2011). The study was carried out to estimate the air quality in the areas with high traffic activity, industrial and suburban zones by means of lichens. For this purpose, the concentrations of 21 chemical elements ( $\mathrm{Al}, \mathrm{As}, \mathrm{Ca}, \mathrm{Cd}, \mathrm{Cr}, \mathrm{Co}, \mathrm{Cu}, \mathrm{Fe}, \mathrm{Hg}, \mathrm{K}$, $\mathrm{Mg}, \mathrm{Mn}, \mathrm{Na}, \mathrm{Ni}, \mathrm{P}, \mathrm{Pb}, \mathrm{S}, \mathrm{Sr}, \mathrm{U}, \mathrm{V}$ and $\mathrm{Zn}$ ) were investigated using Pseudevernia furfuracea (L.) Zopf. samples in bags, which were exposed at 4 different sites in the city of Plovdiv.

\section{Materials and methods}

\section{Study area and sampling sites}

Plovdiv $\left(42^{\circ} 9^{\prime} \mathrm{N}, 24^{\circ} 45^{\prime} \mathrm{E}\right)$ is the second-largest city after the capital Sofia with a population of over 338000 inhabitants (NSI, 2011). It is situated in Southern Bulgaria on the two banks of the Maritsa River. Air quality in Plovdiv is quite worsened due to the motor vehicle emissions and residential heating, than the industrial sector, which has a minor impact (Atanassov et al., 2006; RIOSV, 2010).

For the main purpose of our study, four sites (Northen, Eastern, Western and Central) were selected on the basis of the type of anthropogenic impact (Fig. 1).

The Northern site $\left(\mathrm{N} 42^{\circ} 10^{\prime} 32.3^{\prime \prime}\right.$, E $\left.24^{\circ} 45^{\prime} 53.4^{\prime \prime}\right)$ is located in the city outskirts and was chosen because it is close to an industrial nonresidential area (Northern industrial zone in the city of Plovdiv) where there are a fossil fuel power plant, cosmetic and glass factories, as well as other small-point sources of contaminants.

The Eastern site ( $42^{\circ} 08^{\prime} 24.3^{\prime \prime}$, E $\left.24^{\circ} 47^{\prime} 06.2^{\prime \prime}\right)$ is located in the "Trakiya" suburb, which is characterized by a high traffic and moderate household pressure.

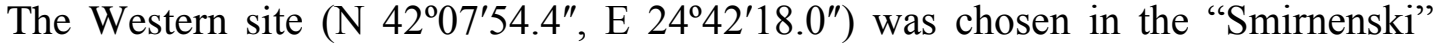
suburb, which is subjected to a moderate anthropogenic impact.

The Central site ( $\left.\mathrm{N} 42^{\circ} 08^{\prime} 22.8^{\prime \prime}, \mathrm{E} 24^{\circ} 44^{\prime} 24.1^{\prime \prime}\right)$ is located in the main center of the city of Plovdiv, along one of the major streets (Ruski Boulevard) with a very intensive daily traffic.

\section{Experimental set up}

Pseudevernia furfuracea (L.) Zopf. was applied as a suitable biomonitor of air pollution. Lichen material was collected from the Vitosha Natural Park, Bulgaria $\left(42^{\circ} 37^{\prime} \mathrm{N}, 23^{\circ} 19^{\prime} \mathrm{E}\right.$, altitude $\left.1710 \mathrm{~m}\right)$ in April 2010. Samples were cleaned from bark 
particles and air-dried in the laboratory. The unwashed material $(3 \mathrm{~g})$ was placed in a nylon mesh $(10 \times 10 \mathrm{~cm})$ and 12 lichen-bags from each site were prepared. A novel hanging system (Fig. 2) at the same height from the ground (approximately 6-7 m) was used in the four studied sites in the city of Plovdiv (north, east, central and west part). Lichen-bags were exposed to the ambient air from May to October 2010.

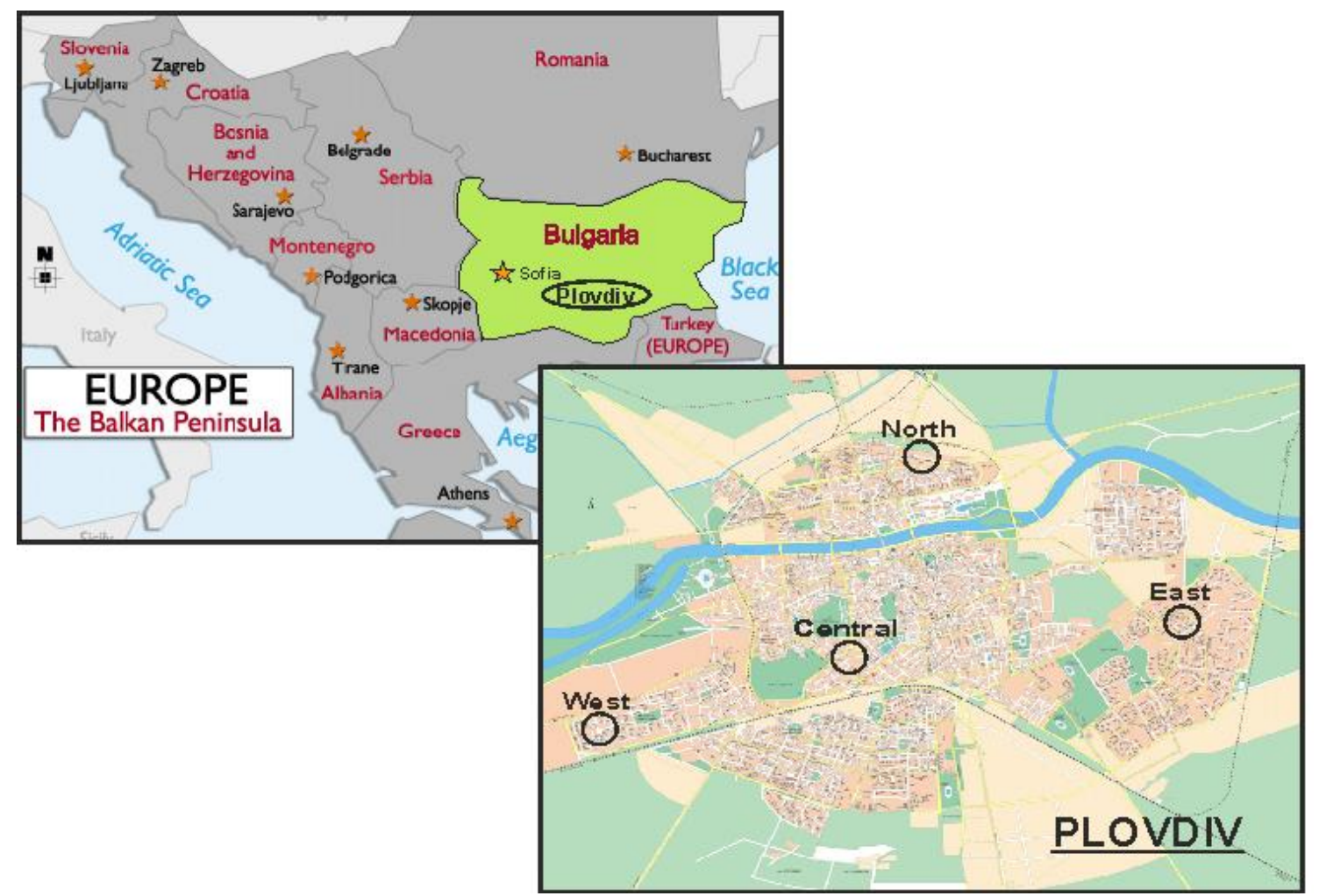

Figure 1. Plovdiv map, which shows the studied sites' location

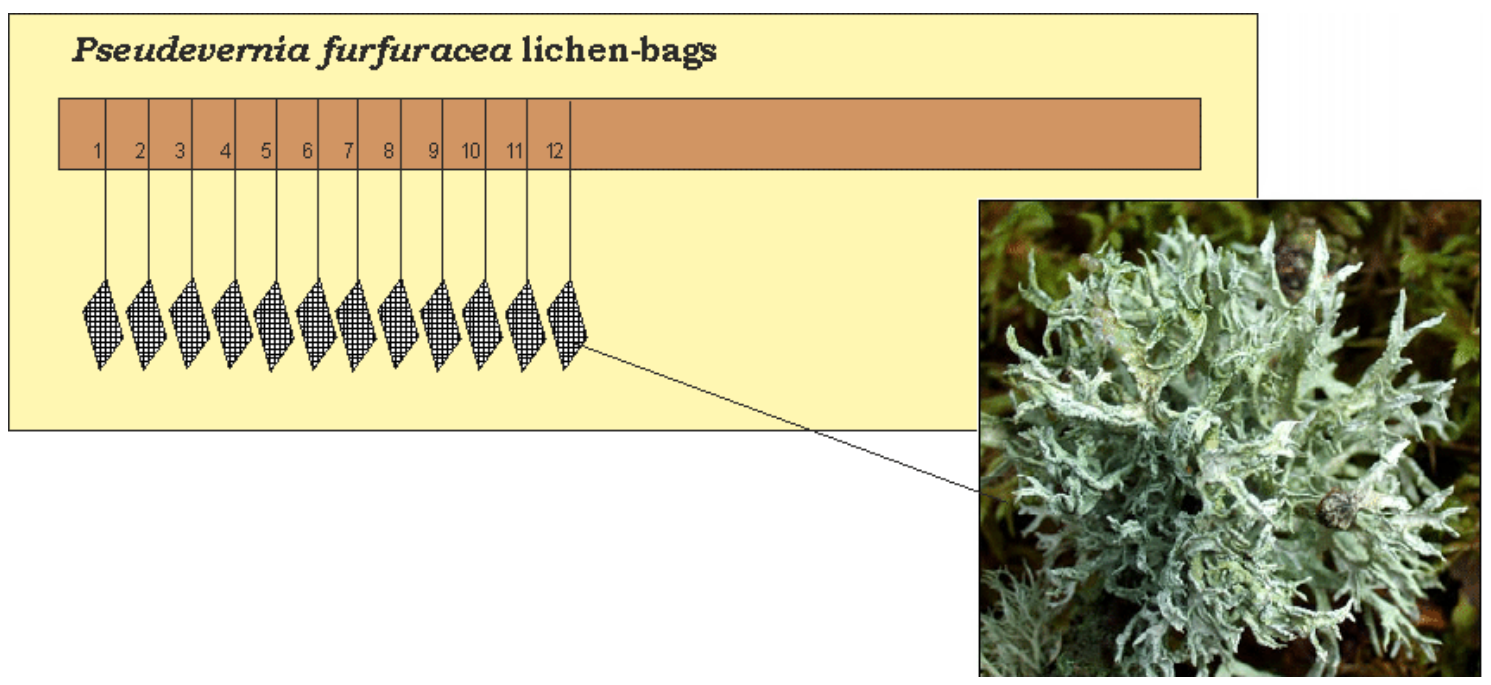

Figure 2. The novel hanging system with lichen-bags 
At the beginning of the experiment and every week during the study, respectively each lichen-bag was carefully moistened with drops of distilled water. Lichens, which were exposed for one, three and five months, respectively were collected at the end of each period and stored in clean, labeled polyethylene bags until chemical analysis.

\section{Analytical procedures}

Approximately $1 \mathrm{~g}$ ground plant material was treated with $5 \mathrm{ml} 65 \% \mathrm{HNO}_{3}$ (Merck) for $24 \mathrm{~h}$ at room temperature. The wet-ashed procedure was carried out with a Microwave Digestion System CEM MDS 81D. Samples were treated for $5 \mathrm{~min}$ at maximum power $(600 \mathrm{~W})$ in closed vessels. After cooling, the vessels were opened and

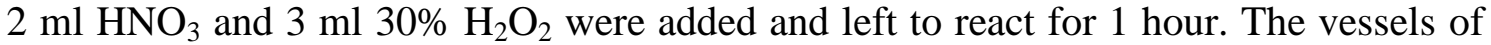
the Microwave Digestion System were closed and treated for $10 \mathrm{~min}$ at $600 \mathrm{~W}$ once again for full digestion of the organic matter. The filtrate was diluted with double distilled water up to $50 \mathrm{ml}$.

All samples, blanks and standards were spiked with internal standards - Ge $50 \mathrm{ppb}$ and Rh 5 ppb final concentration in the solutions. Calibration standards Multy VI (Merck) were freshly prepared from 1 to $1000 \mathrm{ppb}$ in 0.05 volume $\% \mathrm{HNO}_{3}$ (p.a.). Monostandard of $\mathrm{Hg} 100 \mathrm{ppt}$ was also used in the calibration. Signals of suitable isotops for the tested elements were measured twice in both modes - without and with helium gas collision cell.

Concentrations of 22 macro- and microelements were analyzed by FAAS ( $\mathrm{Zn}, \mathrm{Fe}, \mathrm{K}$, $\mathrm{Mg}, \mathrm{Mn}, \mathrm{Na}, \mathrm{Cu}, \mathrm{Ca}$ ) using Atomic Absorption Spectrometer PERKIN-ELMER 4000 and ICP-MS method (Al, S, P, Cr, V, Co, Ni, As, Sr, Mo, Cd, Hg, Pb, U) with instrument Agilent 7700 (2009).

\section{Statistical analysis}

Data analyses using STATISTICA 7.0. for Windows (StatSoft Inc., 2004) were conducted. One-way ANOVA was applied in order to determine the significant differences $(\mathrm{p}<0.05)$ occurring between the element concentrations in the lichen bags from the four studied sites and the unexposed sample.

\section{Results and discussion}

Element concentrations in the transplant material of the lichen biomonitor before and after exposure could be compared to track the anthropogenic load in time (Fig. 3). Macroelements K (up to 4 times), $\mathrm{P}$ and $\mathrm{S}$ decreased their concentrations by extending the exposure period $(\mathrm{p}<0.05)$ in comparison with the unexposed Pseudevernia furfuracea. Loss of $\mathrm{K}$ in moss-bags after exposure has been observed in Sofia by Culicov and Yurukova (2006) and in many other studies (Yurukova and Ganeva, 1997; Adamo et al., 2003; Culicov et al., 2005), but no additional data in respect to loss of macroelements in lichen-bags were found in the literature.

Elements $\mathrm{As}, \mathrm{Cd}, \mathrm{Hg}$ and $\mathrm{U}$ had insignificantly higher concentrations in the unexposed Pseudevernia furfuracea in comparison with the exposed samples. A possible reason for this result could be the higher content of these elements in the background area for the material in Vitosha Mountain as similar results were reported for the moss Sphagnum girgensohnii, collected in the same region (Yurukova et al., 2013). Furthermore, an interesting result for this group of elements (As, $\mathrm{Cd}, \mathrm{Hg}, \mathrm{U}$ ) was 
the dynamics during the three exposure periods: an insignificant decrease of the concentrations between the control (unexposed sample) and exposed lichen after 30 days period (for $\mathrm{Hg}$ - till 90 day), then an increase to 150 day of exposure. Theseelements are connected with burning processes of the fuels, which during the summer were not so heavy as in the winter. Thus a possible explanation for this result could be the emissions emanated from the non-ferrous metallurgy plant, located nearby the city of Plovdiv (to the South direction), as well as the predominant wind from south to north during the period of exposure. This suggestion is supported by the highest concentrations of $\mathrm{As}, \mathrm{Cd}, \mathrm{Hg}$ and $\mathrm{U}$, found in the lichen-bags from the Southern site.

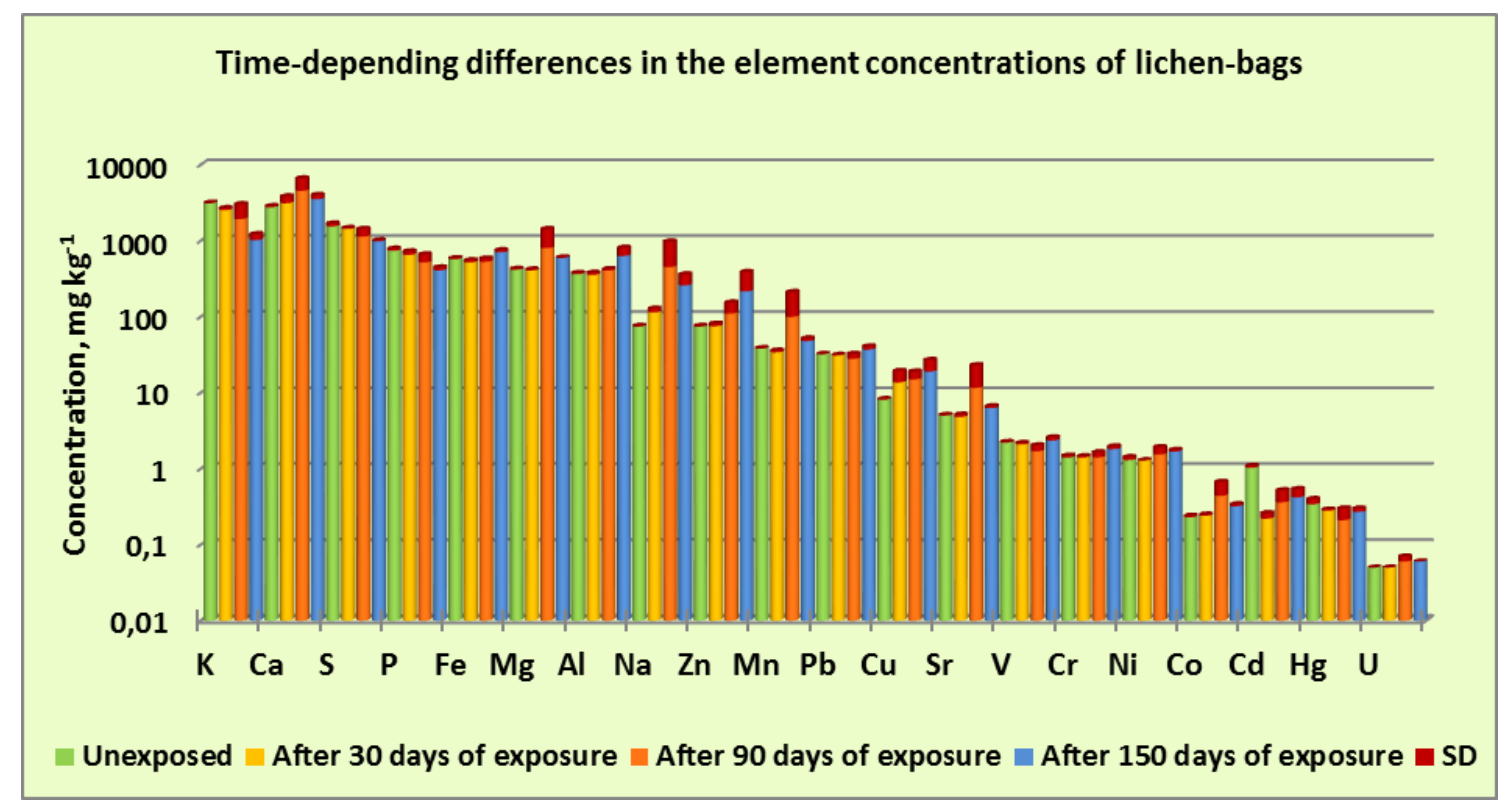

Figure 3. Element concentrations in Pseudevernia furfuracea bags after 30, 90 and 150 days of exposure in the city of Plovdiv

Overall, the reasons for these dynamics in the elements concentrations could be explained by the hypotheses of Sanita di Toppi and Gabrielli (1999). According to them, the $\mathrm{Cd}$ ions are transported into the cell vacuole of phytochelatins and they are accumulated until the ionic binding to the cell wall is less effective. Metal ions are able to bind to the negative charges on the pectin compounds (e.g., galacturonic acid) from the wall by the dynamic conversion process (passive ion exchange). Moreover, the authors state that the dead plant tissue showed a higher cation exchange capacity compared with the live cells, probably due to the destruction of the membrane, allowing the cations to bind more protein regions than in the normal state. On the other hand, some abiotic factors, such as rainfall, can dissolve and wash out the associated cell-wall elements more easily than in the vacuole.

Elements $\mathrm{Al}, \mathrm{Cu}, \mathrm{Ni}$ and $\mathrm{Zn}$ significantly increased their content in lichen-bags with extending the exposure period $(\mathrm{p}<0.05)$. These data correspond with the finding of many authors that used Pseudevernia furfuracea (Basile et al., 2008) and other lichens (Sujetoviene and Sliumpaite, 2013) in urban areas. Element concentrations, which we measured in the lichen-bags from Plovdiv in the present study were higher compared to the results of Basile et al. (2008) from Italy (Cd 1.5 times, $\mathrm{Cu} 4$ times, $\mathrm{Mn} 1.5$ times, $\mathrm{Pb}$, 2 times and $\mathrm{Zn} 9$ times). was quite higher when compared to the data from Italy. 
Relative accumulation factors (RAF) were calculated for all elements as follows: the lichen-bags mean content of each element after 150 days of exposure $\left(\mathrm{C}_{\text {exposed }}\right)$ in all studied sites was divided by the content of each element before exposure $\left(\mathrm{C}_{\text {unexposed }}\right)$.

$$
\mathrm{RAF}=\mathrm{C}_{\text {exposed }} / \mathrm{C}_{\text {unexposed }}
$$

The values of RAF are given in Table 1. Highest values were found for $\mathrm{Na}$ (3.49), $\mathrm{Zn}$ (2.92) and $\mathrm{Cu}$ (3.33). Culicov and Yurukova (2006) reported similar RAF for $\mathrm{Na}$ in lichen-bags from Sofia.

Table 1. Relative accumulation factors (RAF) of the analyzed elements in Pseudevernia furfuracea bags after 150 days of exposure in Plovdiv

\begin{tabular}{|c|c|c|c|}
\hline Element & $\begin{array}{c}\text { Mean content in lichen- } \\
\text { bags after 150 days of } \\
\text { exposure, } \mathrm{mg} \mathrm{kg}^{-1}\end{array}$ & $\begin{array}{c}\text { Content in unexposed } \\
\text { sample Pseudevernia } \\
\text { furfuracea, } \mathrm{mgg}^{-1}\end{array}$ & RAF \\
\hline $\mathrm{Al}$ & 633 & 364 & 1.74 \\
\hline $\mathrm{As}$ & 0.55 & 2.0 & -0.275 \\
\hline $\mathrm{Ca}$ & 3535.5 & 2761 & 1.28 \\
\hline $\mathrm{Cd}$ & 0.425 & 1.03 & -0.41 \\
\hline $\mathrm{Cr}$ & 1.8 & 1.4 & 1.29 \\
\hline $\mathrm{Co}$ & 0.32 & 0.23 & 1.40 \\
\hline $\mathrm{Cu}$ & 18.9 & 8.1 & 2.33 \\
\hline $\mathrm{Fe}$ & 686.75 & 573 & 1.20 \\
\hline $\mathrm{Hg}$ & 0.27 & 0.34 & -0.79 \\
\hline $\mathrm{K}$ & 1020 & 3114 & -0.33 \\
\hline $\mathrm{Mg}$ & 595.25 & 417 & 1.43 \\
\hline $\mathrm{Mn}$ & 47.75 & 38 & 1.26 \\
\hline $\mathrm{Na}$ & 258 & 74 & 3.49 \\
\hline $\mathrm{Ni}$ & 1.675 & 1.3 & 1.29 \\
\hline $\mathrm{P}$ & 407.5 & 740 & -0.55 \\
\hline $\mathrm{Pb}$ & 37 & 32 & 1.16 \\
\hline $\mathrm{S}$ & 984 & 1547 & -0.64 \\
\hline $\mathrm{Sr}$ & 6.3 & 5 & 1.26 \\
\hline $\mathrm{U}$ & 0.06 & 0.05 & 1.2 \\
\hline $\mathrm{V}$ & 2.35 & 2.2 & 1.07 \\
\hline $\mathrm{Zn}$ & 215.75 & 74 & 2.92 \\
\hline
\end{tabular}

Bioaccumulation capability of lichens was determined by their significant cation exchange capacity, which is due to the negatively charged cell wall bases (mostly acidic carboxyl groups), which may also be connected via ionic bonds with the dissolved cations. Elements can be detained and particles can be suspended in the intercellular spaces or on uneven surfaces (Freitas, 1994). Many factors determine the volume and speed of the processes of uptake and release of various elements in lichens, such as chemical characteristics of the element, chemical composition and size of the particles associated with the element, and impact of toxic substances contained in the organism.

In the present study 40 positive and 21 negative correlations were proved for the analyzed elements $(\mathrm{p}<0.05)$. Strongest positive one was found for P, S and K; followed 
by the correlation between $\mathrm{Na}, \mathrm{Ca}, \mathrm{Mg}, \mathrm{Mn}, \mathrm{Ni}, \mathrm{Sr} \mathrm{Cd}$ and $\mathrm{U}$; as well as $\mathrm{Al}, \mathrm{V}, \mathrm{Pb}, \mathrm{Cr}$ and $\mathrm{Fe}$. Negative relationships existed between the macroelements and the group of heavy metals.

Site-depending differences are presented in Fig. 4. Mean concentrations of K, Ca, S, P, $\mathrm{Fe}$ and $\mathrm{Mg}$ proved insignificant differences in the lichen-bags exposed in the studied sites.

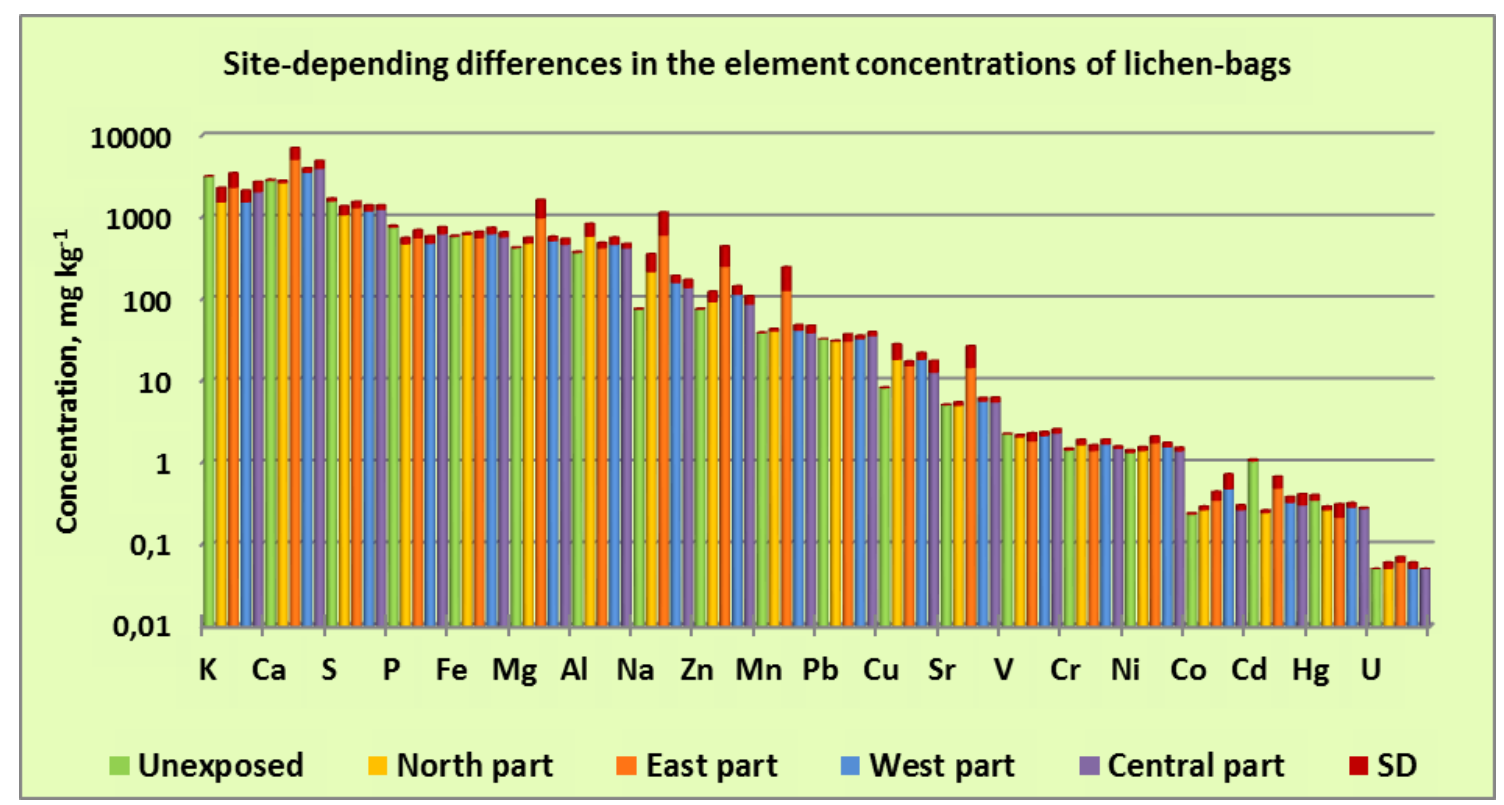

Figure 4. Element concentrations in Pseudevernia furfuracea bags after 150 days of exposure in four selected sites in the city of Plovdiv

A tendency to enlarge the number of maximal values of the elements $(\mathrm{P}, \mathrm{Pb}, \mathrm{V}, \mathrm{Cr}$, $\mathrm{Hg}, \mathrm{Fe}$ ) by approaching the central part of Plovdiv was found. The Eastern zone was characterized with highest concentrations of $\mathrm{K}, \mathrm{Ca}, \mathrm{S}, \mathrm{Mg}, \mathrm{Na}, \mathrm{Zn}, \mathrm{Mn}, \mathrm{Sr}, \mathrm{Ni}, \mathrm{Cd}$ and U. However, none of the elements had highest concentrations in the Western site. In addition, the applied cluster analysis showed a close relationship between the Northern and Western sites, connected then with the Central zone but quite separated from the Eastern site (Fig. 5).

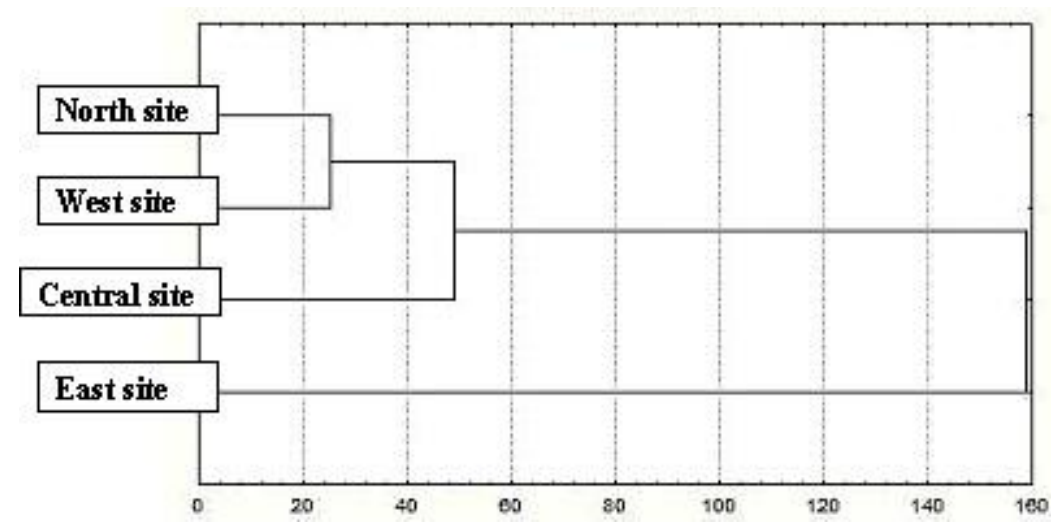

Figure5. Cluster analysis of the studied sites in the city of Plovdiv based on element content in Pseudevernia furfuracea bags after 150 days of exposure 


\section{Conclusions}

In general, in the present study it was attempted to describe and assess the atmospheric pollution levels in the city of Plovdiv using lichen-bags technique for three periods. $\mathrm{Na}, \mathrm{Mn}, \mathrm{Cu}, \mathrm{Zn}$ and $\mathrm{Sr}$ increased significantly their concentrations in the lichen-bags, whereas $\mathrm{K}, \mathrm{S}$ and $\mathrm{Cd}$ decreased theirs in comparison with the unexposed lichenized fungi. Highest concentrations of 11 elements were measured in the collectors, which were exposed in the Eastern site of the urban area, probably due to non-ferrous complex nearby.

Pearson's analysis showed a strong positive correlation between the macronutrients $\mathrm{P}$, $\mathrm{S}$ and $\mathrm{K}$, followed by the correlation between $\mathrm{Na}, \mathrm{Ca}, \mathrm{Mg}, \mathrm{Mn}, \mathrm{Ni}, \mathrm{Sr}, \mathrm{Cd}$ and $\mathrm{U}$, and lastly between $\mathrm{Al}, \mathrm{V}, \mathrm{Pb}, \mathrm{Cr}$ and $\mathrm{Fe}$, which mainly indicates the vehicle emissions impact.

We can conclude that this study confirms that the species Pseudevernia furfuracea is an efficient element accumulator in lichen-bags exposed in urban areas. Moreover, the results from this preliminary study can be successfully used in future comparative analyses for the atmospheric pollution and risk assessment in similar urban areas.

Acknowledgements. We are grateful to Dr. V. Kmetov (Head of the Department of Analytical Chemistry, University of Plovdiv), Dr. V. Stefanova and their group for the element determinations, included in the GAMA (Green Analytical Methods Academic Centre) Project, funded by National Scientific Fund (Bulgaria). In memoriam of our dear colleague and friend Prof. Lilyana Yurukova.

\section{REFERENCES}

[1] Adamo, P., Giordano, S., Vingiani, S., Castaldo-Cobianchi, R., Violante, P. (2003): Trace element accumulation by moss and lichen bags in the city of Naples (Italy) Environmental Pollution 122: 91-103.

[2] Atanassov, D., Spassova, S., Grancharova, D., Krastev, S., Yankova, T., Nikolov, L., Chakarova, M., Krasteva, P., Genov, N., Stamenov, J., Dimitrov, E. (2006): Air pollution monitoring and modeling system of the town of Plovdiv (Phase I) - Journal of Environmental Protection and Ecology 7(2): 260-268.

[3] Basile, A., Sorbo, S., Aprile, G., Conte, B., Castaldo-Cobianchi, R. (2008): Comparison of the heavy metal bioaccumulation capacity of an epiphytic moss and an epiphytic lichen - Environmental Pollution 151: 401-407.

[4] Bermudez, G., Rodriguez, J., Pignata, M. (2009): Comparison of the air pollution biomonitoring ability of three Tillandsia species and the lichen Ramalina celastri in Argentina - Environmental Research 109: 6-14.

[5] Cansaran-Duman, D., Aras, S., Atakol, O., Atasoy, I. (2012): Accumulation of trace elements and the assessment of the genotoxicity in the lichen Pseudevernia furfuracea transplanted to a polluted site in Ankara - Ekoloji 21(85): 1-14

[6] Conti, M.E., Geccheti, G. (2001): Biological monitoring: lichens as bioindicators of air pollution assessment: a review - Environmental Pollution 114: 471-492.

[7] Culicov, O.A., Yurukova, L. (2006): Comparison of element accumulation of different moss- and lichen-bags, exposed in the city of Sofia (Bulgaria) - Journal of Atmospheric Chemistry 55: 1-12.

[8] Culicov, O.A., Mocanu, R., Frontasyeva, M.V., Yurukova, L., Steinnes, E. (2005): Active moss biomonitoring applied to an industrial site in Romania: Relativa accumulation of 36 elements in moss-bags - Environmental Monitoring and Assessment 108: 229-240. 
[9] Giordano, S., Adamo, P., Sorbo, S., Vingiani, S. (2005): Atmospheric trace metal pollution in the Naples urban area based on results from moss and lichen bags Environmental Pollution 136: 431-442.

[10] Monaci, F., Moni, F., Panciotti, E., Grechi, D., Bargagli, R. (2000): Biomonitoring of airborne metals in urban environments: New tracers of vehicle emissions, in place of lead - Environmental Pollution 107: 321-327.

[11] RIOSV-Plovdiv. (2013): Annual report of environmental quality in the region of Plovdiv. Available at: http://plovdiv.riosv.com/files/godishni_dokladi/god-2010.pdf

[12] Sawidis, T., Marnasidis, A., Zachariadis, G., Stratis, J. (1995): A study of air pollution with heavy metals in Thessaloniki city (Greece) using trees as biological indicators Archives of Environmental Contamination and Toxicology 28(1): 118-124.

[13] Sczepaniak, K., Biziuk, M. (2003): Aspects of the biomonitoring studies using mossesand lichens as indicators of metal pollution - Environmental Research 93: 221-230.

[14] Sujetoviene, G., Sliumpaite, I. (2013): Response of Evernia prunastri transplanted to an urban area in central Lithuania - Atmospheric Pollution Research 4: 222-228.

[15] Yildiz, A., Aksoy, A., Tug, G.N., Islek, C., Demirezen, D. (2008): Biomonitoring of heavy metals by Pseudevernia furfuracea (L.) Zopf in Ankara (Turkey) - Journal of Atmospheric Chemistry 60: 71-81.

[16] Yurukova, L., Ganeva, A. (1997): Active biomonitoring of atmospheric element deposition with Sphagnum species around a copper smelter in Bulgaria - Angewandte Botanik 71: 14-20.

[17] Yurukova, L., Petrova, S., Velcheva, I., Aleksieva, I. (2013): Preliminary data of mossbags technique in an urban area (Plovdiv, Bulgaria) - Comptes Rendue de l'Academie bulgare des Sciences 66(8): 1135-1138. 